\title{
PEMANFAATAN ETNOBOTANI JENIS-JENIS TANAMAN OBAT DI DUSUN WAINUSALAUT DESA SULI KECAMATAN SALAHUTU KABUPATEN MALUKU TENGAH DAN IMPLIKASINYA SEBAGAI BAHAN AJAR MATA KULIAH BOTANI TUMBUHAN TINGGI
}

\author{
Ruslia Pulu1, Alwi Smith² \\ ${ }^{1}$ Alumni Program Studi Pendidikan Biologi \\ ${ }^{2}$ Staf Pengajar Program Studi Pendidikan Biologi \\ E-mail: alwi.smith1963@gmail.com
}

\begin{abstract}
Background: Medicinal plants are all plants that can be used as medicine, ranging from those seen by the eye to those that appear under a microscope. Medicinal plants are all types of medicinal plants that are known or believed to have medicinal properties, which are grouped into traditional medicinal plants. The purpose of this study was to determine the types of medicinal plants used by the people of Wainusalaut Village as traditional medicine.

Method: This type of research is qualitative with survey and interview techniques.

Results: Research shows that 24 types of medicinal plants have been known to have been cultivated by the people of Wainusalaut Village and which have the potential as a drug as many as 18 species of plants that enter into 20 families. The part that is often used by the villagers of Wainusalaut is stems, roots, leaves and fruit.

Conclusion: There are 24 types of medicinal plants that have been cultivated by the people of Wainusalaut Village.
\end{abstract}

Keywords: Ethnobotany, medicinal plants, Waitusalaut.

\begin{abstract}
Abstrak
Latar Belakang: Tanaman obat adalah semua tanaman yang dapat digunakan sebagai obat, berkisar dari yang terlihat oleh mata hingga yang nampak di bawah mikroskop. Tanaman obat adalah seluruh jenis tanaman obat yang diketahui atau dipercaya mempunyai khasiat obat, yang dikelompokkan menjadi tanaman obat tradisional. Tujuan penelitian ini adalah untuk mengetahui jenis-jenis tanaman obat yang dimanfaatkan oleh masyarakat Desa Wainusalaut sebagai obat tradisional.

Metode: Jenis penelitian ini adalah kualitatif dengan teknik survey dan wawancara.

Hasil: Penelitian menunjukan bahwa 24 jenis tanaman obat telah diketahui sudah dibudidayakan oleh masyarakat Desa Wainusalaut dan yang berpotensi sebagai obat sebanyak 18 jenis tanaman yang masuk kedalam 20 famili. Bagian yang sering digunakan oleh masyarakat dusun wainusalaut adalah batang, akar, daun dan buah.

Kesimpulan: Terdapat 24 jenis tanaman obat sudah dibudidayakan oleh masyakarat Desa Wainusalaut.
\end{abstract}

Kata Kunci: Etnobotani, tanaman obat, Wainusalaut. 


\section{PENDAHULUAN}

Tanaman obat adalah semua tanaman yang dapat digunakan sebagai obat, berkisar dari yang terlihat oleh mata hingga yang nampak dibawah mikroskop (Dewi Kusuma 2012). Tanaman obat adalah seluruh jenis tanaman obat yang diketahui atau dipercaya mempunyai khasiat obat, yang dikelompokkan menjadi tanaman obat tradisional yaitu jenis tanaman obat yang diketahui atau dipercaya oleh masyarakat mempun yai khasiat obat dan telah digunakan sebagai bahan baku obat tradisional. Tanaman obat moderen, yaitu jenis tanaman yang secara ilmiah telah dibuktikan mengandung senyawa atau bahan bioaktif yang berkhasiat obat dan penggunaannya dapat dipertanggungjawabkan secara medis.

Tanaman obat potensial, yaitu; jenis tanaman obat yang diduga mengandung senyawa atau bahan aktif yang berkhasiat obat, tetapi belum dibuktikan Sejalan dengan perkembangan industri jamu, obat herbal, fitorarmaka, dan kosmetika tradisional juga mendorong berkembanganya budidaya tanaman obat di Indonesia .

Tanaman obat merupakan salah satu bentuk interaksi antara masyarakat dengan lingkungan alamnya. Interaksi pada setiap suku memiliki karakteristik tersendiri dengan bergantung pada karakteristik wilayah dan potensi kekayaan tanaman yang ada. Pengkajian tanaman obat menurut etnobotani suku tertentu bermaksud untuk mendokumentasikan potensi sumber daya tumbuhan obat dan merupakan upaya untuk mengembangkan dan melestarikannya.

Selama ini upaya penyediaan bahan baku untuk industri obat tradisional sebagaian besar berasal dari tanamantanaman yang tumbuh liar atau dibudidayakan dalam skala kecil di lingkungan sekitar rumah dengan kuantitas perkembangannya sering dijumpai ketidak tetapan penggunaan obat tradisional karena kesalahan informasi maupun anggapan keliru terhadap obat tradisional dan cara penggunaannya. Penggunaan obat tradisional (herbal) perlu diperhatikan bila ditinjau dari kepastian bahan efektif yang belum dijamin terutama untuk penggunaan secara rutin.
Tanaman obat merupakan salah satu bentuk interaksi anatara masyarakat dengan lingkungan alamnya. Interaksi pada setiap suku memiliki karakteristik tersendiri dengan bergantung pada karakteristik wilayah dan potensi kekayaan tumbuhan yang ada. Pengkajian tanaman obat menurut etnobotani suku tertentu bermaksud untuk mendokumentasikan potensi sumber daya tanman obat dan merupakan upaya untuk mengembangkan dan melestarikannya (Kuswardana W, 2005).

Penggunaan bahan alam sebagai obat cenderung mengalami peningkatan dengan adanya isu back tonature dan krisis berkepanjangan yang mengakibatkan turunnya daya beli masyarakat terhadap obat-obat moderen yang relatif lebih mahal harganya. Obat bahan alami juga dianggap hampir tidak memiliki efek samping yang membahayakan. Untuk menunjukan obat alternatif dalam pengobatan moderen, pemakayaan obat tradisional jenis herbal (dari tumbuhan tidak cukup hanya melalui uji empiris maupun pra-klinis. Untuk menyakinkan khasiatnya dan bisa dikembangkan pihak industri dalam skala yang lebih besar, obat herbal harus diuji secara klinik. Hal ini disebabkan dalam Tanaman obat merupakan salah satu bentuk interaksi anatara masyarakat dengan lingkungan alamnya. Interaksi pada setiap suku memiliki karakteristik tersendiri dengan bergantung pada karakteristik wilayah dan potensi kekayaan tumbuhan yang ada. Pengkajian tanaman obat menurut etnobotani suku tertentu bermaksudkan untuk mendokumentasikan potensi sumber daya tanman obat dan merupakan upaya untuk mengembangkan dan melestarikannya (Ginting N, 2016).

\section{MATERI DAN METODE}

Jenis penelitian ini adalah survei, dan angket yang dibuktikan langsung dengan fakta keberadaan tanaman yang dimaksud di lapangan. Populasi adalah masyarakat menggunakan tumbuhan obat tradisional di Dusun Wainusalaut Desa Suli Kecamatan Salahutu Kabupaten Maluku Tengah yang berjumlah $60 \mathrm{KK}$. Sampel dalam penelitian ini akan diambil secara purposive sampling di dusun wainusalaut sebanyak $60 \mathrm{KK}$. 
Instrumen yang digunakan dalam penelitian ini adalah observasi, wawancara, kuesioner. Variabel dalam penelitian ini adalah variabel tunggal yaitu jenis-jenis tanaman obat serta pemanfaatan sebagai obat tradisional.

\section{HASIL DAN PEMBAHASAN}

Penggunaan bahan alam sebagai obat cenderung mengalami peningkatan dengan adanya isu back tonature dan krisis berkepanjangan yang mengakibatkan turunnya daya beli masyarakat terhadap obat-obat moderen yang relatif lebih mahal harganya. Obat bahan alami juga dianggap hampir tidak memiliki efek samping yang membahayakan. Untuk menunjukan obat alternatif dalam pengobatan moderen, pemakayaan obat tradisional jenis herbal (dari tumbuhan tidak cukup hanya melalui uji empiris maupun pra-klinis. Untuk menyakinkan khasiatnya dan bisa dikembangkan pihak industri dalam skala yang lebih besar, obat herbal harus diuji secara klinik. Hal ini disebabkan dalam Tanaman obat merupakan salah satu bentuk interaksi anatara masyarakat dengan lingkungan alamnya. Interaksi pada setiap suku memiliki karakteristik tersendiri dengan bergantung pada karakteristik wilayah dan potensi kekayaan tumbuhan yang ada. Pengkajian tanaman obat menurut etnobotani suku tertentu bermaksudkan untuk mendokumentasikan potensi sumber daya tanman obat dan merupakan upaya untuk mengembangkan dan melestarikan (Iswandono E, 2015).

Berdasarkan hasil wawancara dan pengamatan di lapangan, tanaman obat yang dimanfaatkan oleh masyarakat dusun wainusalaut sebanyak 24 Jenis tanaman obat yang dimanfaatkan sebagai pengobatan tradisional.

Berdasarkan hasil wawancara yang dilakukan telah diketahui bahwa 24 jenis tanaman obat telah diketahui sudah dibudidayakan oleh masyarakat dusun wainusalaut, baik itu di pekarangan rumah maupun di tanam di kebun. Bagian tumbuhan obat yang di gunakan sebagai obat oleh masyarakat dusun wainusalaut dari berbagai literature, terdapat jenis-jenis tanaman yang dimanfaatkan yang berpotensi sebagai obat sebanyak 18 jenis tanaman obat yang masuk kedalam 20 famili. Tanaman obat ini ada yang masih berupa tanaman liar dan ada yang sudah dibudidayakan oleh masyakarat wainusalaut. tanaman obat yang telah masyarakat dusun wainusalaut dimanfaatkan untuk pengobatan obat tradisional dan untuk mengobati penyakit mereka. Menurut masyarakat dusun wainusalaut pengobatan dengan obat tradisional sudah menjadi kebiasan masyarakat dusun wainusalauti (Irmawati, 2016).

Responden dalam penelitian ini adalah bapak/ibu dalam pengobatan tradisional yang berjumlah 8 orang terdiri dari 4 orang laki-laki dan 4 orang perempuan yang terlihat pada tabel 1.

Tabel 1. Daftar Nama Responden Berdasarkan Umur dan Jenis Kelamin

\begin{tabular}{lllll}
\hline No & Daftar nama & Umur & Jenis Kelamin & Pendidikan \\
\hline 1 & Bp L & 61 Tahun & Laki-laki & Tidak Ada \\
2 & lbu K & 58 Tahun & Perempuan & SMA \\
3 & Bp J & 65 Tahun & Laki-laki & SD \\
4 & lbu W & 78 Tahun & Perempuan & SMP \\
5 & Bp R & 70 Tahun & Laki-laki & SMA \\
6 & lbu L & 60 Tahun & Perempuan & SMP \\
7 & Bp L & 75 Tahun & Laki-laki & SD \\
8 & lbu M & 59 Tahun & Perempuan & SMA \\
\hline
\end{tabular}

Jenis tanaman obat yang dimanfaatkan masyarakat dusun wainusalaut sejek oleh masyarakat dusun wainusalaut zaman dahulu. Berdasarkan hasil sebagian besar adalah tanaman yang wawancara yang dilakukan di Dusun terdapat di hutan dan jenis-jenis yang Wainusalaut terdapat 18 spesies yang dimanfaatkan untuk pengobatan darah ditemukan tanaman obat yang tinggi sangat banyak dimanfaatkan oleh dimanfaatkan sebagai obat oleh 
masyarakat dusun wainusalaut menggunakan obat-obatan tradisional, misalnya (Persea Americana) merupakan tanaman yang diketahui oleh masyarakat dusun wainusalaut dan dimanfaatkan dalam kehidupan sehari-hari. Kebiasaan masyarakat dusun wainusalaut ini diwariskan secara turun temurun dari generasi dahulu sampai generasi sekarang misalnya, Averrhoa carambola ( belimbing) untuk mengobati penyakit darah tinggi dan kulit berjerawat. Masyarakat dusun wainusalaut manfaatkan tanaman obat sangat banyak selain itu masyarakat juga mengunakan sebagai obat tradisional yang digunakan sebagai bahan masak oleh masyarakat dusun wainusalaut. Selain itu kunyit juga dimanfaatkan masyarakat sebagai bumbu masakan, rempah, bahan pangan, pengwaget, pewarna, dan bahan baku cat. Kunyit juga mempunyai peranan penting di bidang kesehatan masyarakat karena khasiatnya sebagai jamu dan obat herbal tradisional yang efektif, murah, aman.menurut (Husain Asmi,2005)

Pengobatan tradisional dan obat tradisional telah menyatu dengan masyarakat dusun wainusalaut bagian tanaman yang digunakan dalam mengatasi berbagai masalah kemampuan masyarakat dusun wainusalaut untuk mengobati penyakit sendiri. Untuk itu pelayanan kesehatan tradisional merupakan potensi besar karena dekat dengan masyarakat dusun wainusalaut yang mudah diperoleh dan relatif lebih murah dari pada obat moderen.menurut (Juni Tanjungsari R, 2005).

Jenis penyakit yang dapat diobati oleh masyarakat dusun wainusalaut adalah darah tinggi, diare, sakit pinggang, demam, batuk, keputihan, patah tulang, sakit gigi. Jenis tanaman obat yang paling banyak digunakann untuk mengobati penyakit pada masyarakat dusun wainusalaut jenis-jenis adalah Persea Americana, Citrus aurantifolia, Zingiber officinale, Curcuma longa, Garcinia mangostana, Piper betle, Syzygium aromaticum Merr, Anredera cordifolia. Sedangkan satu jenis tanaman obat yang digunakan untuk mengobati penyakit adalah Anredera cordifolia dalam pemanfaatannya jenis tanaman obat ini cukup mudah digunakan karena daunnya dapat digunakan mengobati penyakit langsung tanpa harus di rebus terlebih dahulu. Masyarakat dusn wainusalaut sangat memanfaatkan tanaman obat tradisional sebagai pengobatan penyakit yang di derita pada anak-anak . Masyarakat dusun wainusalaut masih menjadikan obatobatan tradisional sebagai obat alternatif dari pada dibandingkan dengan obat Puskesmas atau di rumah sakit. Masyarakat dusun wainusalaut percaya bahwa pengobatan tradisional sangat bagus untuk mengobati suatu penyakit dan tidak memiliki efek samping terhadap penyakit lain. Selain itu obat-obatan tradisional sangat mudah didapatkan tanpa harus mengeluarkan uang. Secara umum pengetahuan tanaman obat yang masyarakat dusun wainusalaut ketahui diperoleh secara turun temurun dari orang tuannya, pengetahuan ini merupakan hasil interaksi dan komunikasi dalam kehidupan sehari-hari oleh masyarakat dusun wainusalaut (Aryadi M, Fitria, 2014).

\section{KESIMPULAN}

Berdasarkan hasil penelitian dan pembahasan dapat disimpulkan beberapa anatara lain. bahwa 24 jenis tanaman obat telah diketahui sudah dibudidayakan oleh masyarakat dusun wainusalaut, baik itu di pekarangan rumah maupun di tanam di kebun. Bagian tumbuhan obat yang di gunakan sebagai obat oleh masyarakat dusun wainusalaut dari berbagai literature, terdapat jenis-jenis tanaman yang dimanfaatkan yang berpotensi sebagai obat sebanyak 18 jenis tanaman obat yang masuk kedalam 20 famili. Tanaman obat ini ada yang masih berupa tanaman liar dan ada yang sudah dibudidayakan oleh masyakarat wainusalaut. tanaman obat yang telah masyarakat dusun wainusalaut dimanfaatkan untuk pengobatan obat tradisional dan untuk mengobati penyakit mereka ( Atmojo Eko S, 2003).

\section{DAFTAR PUSTAKA}

Aryadi M, Fithria A, Susilawati, Fatria, 2014, Kearifan lokal masyarakat dayak terhadap tumbuhan berkhasiat obat di lahan agroforest kabupaten barito utara fakultas kehutanan universitas lampung 
mangkurat BLHD kab. Barito utara, Vol 2 (3).

Atmojo Eko S, 2003, Pengenalan Enntobotani Pemanfaatan Tanaman Sebagai Obat Kepada Masyarakat Desa Cabak Jiken Kabupaten Blora, FKIP Universitas PGRI Yongyakarta.

Dewi Kusuma I, Winarso A, Yuandrita R, 2012, Pengetahuan lbu Tentang Pemanfaatan Tanaman Obat Untuk Asam Urat, Kementrian Kesehatan, Politeknik Kesehatan Surakarta Jurusan Jamu.

Husain Asmi N, 2015, Studi Entobotani dan Identifikasi Tumbuhan Berkhasiat Obat Berbasis Pengetahuan Lokal di Kabupaten Enrekang, Program Studi Agroteknologi Jurusan Budidaya Pertanian, Fakultas Pertanian Universitas Hasanudin Makassar.

Irmawati, 2016, Entobotani tumbuhan berkhasiat obat oleh suku dayak ngaju di wilayah kelurahan tumbang senamang kecamatan katingan hulu kabupaten katingan fakultas tarbiyah dan ilmu keguruan jurusan pendidikan MIPA program studi tadris biologi.

Juni Tanjungsari $R, M$ Zuhud A.E, Damayanti, K.E, 2015 Manfaat kampung konservasi tumbuhan obat keluarga (Toga) gunung leutik, desa banteng ciampea bogor Vo. 20, No,1, Departemen Konservasi Sumberdaya Hutan dan Ekowisata Fakultas Kehutanan IPB, PO BOX 168, Bogor 1668

Ginting N, 2016, Entobotani Tumbuhan Obat di Desa Siharangkarang Vol. 3, No, 1, Prodi Pendidikan Biologi FKIP, Universitas Muhammdiaya Tapanuli Selatan

Kuswardana W, Ningsih N.Triasti, Tjitrosoepomo, Ismanto, 2005 invertarisasi jenis-jenis tumbuhan obat yang digunakan oleh masyarakat suku baduy luar program studi biologi, FMIPA universitas pakuan, JL. Pakuan P.O. Box 452, bogor.

Iswandono $E$, Muhammad zuhud A. E, Hikma A, Kosmaryandi N, 2015, pengetahuan entobotani suku manggarai dan implikasinnya terhadapat pemanfaatan tumbuhan hutan di pegununggan ruteng ilmu pertanian indionesia ,vol 20(3) : 171181. 